\title{
Effects of general anaesthesia on size of cerebrospinal fluid spaces during and after pneumoencephalography
}

\author{
I. F . MOSELEY, L. LOH, A N D G H . d u B O U LA Y
}

From the Lysholm Department of Radiology, and the Department of Anaesthesia, National Hospital, Queen Square, London

SUMMARY The mode of anaesthesia used during pneumoencephalography has a significant effect on the size of the cerebral ventricles 24 hours after the procedure. Post-encephalographic ventricular enlargement is less marked in patients examined under nitrous oxide anaesthesia. This appears to be related to passage of the gas into the ventricles during the encephalogram, and subsequent diffusion outwards. Variations in arterial carbon dioxide tension during the anaesthesia do not contribute significantly to changes in ventricular size. However, both hyperventilation and inhalation of nitrous oxide may cause apparent increase in size of the cerebral sulci.

Moseley and Sondheimer (1975) analysed the changes in size of the lateral ventricles seen after pneumoencephalography in 150 patients, of whom the large majority (142) were examined using local anaesthesia. Nitrous oxide was used as the anaesthetic agent in two of the remaining cases. The findings indicated that increases in ventricular size occurring at 24 hours were more directly related to the presence of a diseased brain or to a disturbance of the cerebrospinal fluid dynamics (particularly the latter) than to the volume of air injected, the age of the patient, the presence of air in the subdural space, or a history of head injury. The present study extends this analysis to a group of patients examined under general anaesthesia, and describes an investigation into possible explanations of the differences observed.

\section{Materials and methods}

COMPARISON OF LOCAL AND GENERAL ANAESTHESIA The encephalograms of all patients in whom satisfactory radiographs had been obtained at 24 hours or longer after the injection of air performed at the National Hospital, Queen Square from 1959 to 1976 were reviewed. All these patients had undergone general anaesthesia, with inhalation of nitrous oxide in approximately $70 \%$ concentration.

Address for reprint requests: Dr Ivan Moseley, Lysholm Department of Radiology, The National Hospital, Queen Square, London WCIN 3BG.

Accepted 2 June 1977
The procedure was otherwise identical to that described by Moseley and Sondheimer (1975), except that in most of the earlier examinations the somersaulting chair had not been available.

Ventricular mensuration was limited to the LeMay index (LeMay, 1967), on radiographs obtained during the encephalogram (usually towards its conclusion), 24 hours later, and at further intervals where possible. The reasons for the choice of this single index were discussed by Moseley and Sondheimer (1975).

VARIATIONS IN ARTERIAL CARBON DIOXIDE TENSION Twelve patients undergoing pneumoencephalography for the investigation of suspected intracranial diseases were anaesthetised in the manner adopted as routine in this hospital: atropine, 0.6 $\mathrm{mg}$ was given as premedication; the patients were preoxygenated, and the standard doses of methohexitone and suxamethonium were given for induction of anaesthesia and orotracheal intubation. Anaesthesia was maintained with $0.5 \%$ trichloroethylene and $33 \%$ oxygen in nitrous oxide. Intermittent positive pressure respiration with pancuronium as a muscle relaxant ensured that ventilation was adequate and remained constant.

The encephalogram was then carried out in the usual way, as dictated by the clinical problem and the radiological findings. At the end of the routine portion of the study, with the patient in the 'browup' position, the end-expired $\mathrm{CO}_{2}$ percentage was measured, using an infra-red analyser (Capno- 
graph). The blood pressure was recorded, and an anteroposterior radiograph of the whole head obtained.

Arterial $\mathrm{PCO}_{2}$ was then altered by changing the $\mathrm{CO}_{2}$ concentration in the inspired gas (increasing it in nine cases and decreasing it in three), and when the end-expired $\mathrm{CO}_{2}$ reading had been stable for from three to 10 minutes, the blood pressure was again recorded and a further radiograph obtained. The inspired gas mixture was then returned to its original composition and, after a further period of stabilisation, a further radiograph, accompanied by a blood pressure reading, was obtained. Neither the patient nor the radiographic apparatus was moved between the exposures.

Mensuration The LeMay index was measured on each of the three radiographs. An attempt was also made to assess the width of such cerebral sulci as were clearly visible on all three radiographs of each patient. A $0.1 \mathrm{~mm}$ graticule was used to make these measurements and, whenever possible, three sulci from each hemisphere were assessed; the 'mean sulcus diameter' was the mean width of the sulci measured on any one radiograph.

\section{EFFECTS OF NITROUS OXIDE INHALATION}

Ten patients undergoing pneumoencephalography were anaesthetised as described in the previous section, except that the anaesthetic machine had been modified so that the patients could be ventilated with a mixture which was largely air: not less than $0.5 \%$ trichloroethylene and $33 \%$ oxygen in nitrogen.

The encephalogram was carried out in the usual way, and at the end of the first 'brow-up' series, an anteroposterior radiograph of the whole head was obtained, and the blood pressure recorded. The inspired gas mixture was then changed to $33 \%$ oxygen in nitrous oxide, without changing the trichloroethylene concentration or the minute volume ventilation; the latter was checked with a respirometer.

Further anteroposterior films of the head were obtained at intervals up to 20 minutes, without any movement of the patient or the radiographic apparatus. The encephalogram was then continued. At its termination, with the patient once again in the 'brow-up' position, another radiograph was obtained, the inspired gas mixture was returned to its original composition - that is, the nitrous oxide was discontinued-and a further series of films exposed, as before, up to 15 minutes.

A further 10 patients were subjected to routine pneumoencephalography using nitrous oxide throughout.

Mensuration Measurements were made of the
LeMay index, and of the third ventricle index (the maximum transverse diameter of the third ventricle divided by the maximum external transverse diameter of the skull) on all the specially obtained radiographs. Similar measurements were made on the 'brow-up' films of the 'control' patients who breathed nitrous oxide throughout. The sulci were also measured, as described previously; it should be noted that it was frequently necessary to measure different sulci on the two series obtained during and after nitrous oxide inhalation.

\section{Results}

PATIENTS EXAMINED UNDER NITROUS OXIDE ANAESTHESIA

There were 79 patients who fell into the five diagnostic categories defined by Moseley and Sondheimer (1975); their distribution is shown in Table 1.

Table 1 Pneumoencephalograms under nitrous oxide anaesthesia-patient population

\begin{tabular}{|c|c|c|c|c|}
\hline \multicolumn{3}{|c|}{ Group } & \multirow{2}{*}{$\begin{array}{l}\text { Number } \\
12 \\
14 \\
22 \\
18 \\
13\end{array}$} & \multirow{2}{*}{$\begin{array}{l}\text { Percentage of total } \\
15 \\
18 \\
28 \\
23 \\
16\end{array}$} \\
\hline $\begin{array}{l}\text { A } \\
\text { B } \\
\text { C } \\
\text { D } \\
\text { E }\end{array}$ & $\begin{array}{l}\text { Normal } \\
\text { Cortical atrophy } \\
\text { Generalised atrophy } \\
\text { Normal pressure hydrocep } \\
\text { Other } \\
\text { Equivocal } \\
\text { Space-occupying lesion } \\
\text { Other hydrocephalus } \\
\text { Chiari malformation }\end{array}$ & $\begin{array}{l}\text { halus } \\
8 \\
2 \\
2 \\
1\end{array}$ & & \\
\hline Tota & 1 & & 79 & 100 \\
\hline
\end{tabular}

Table 2 shows the changes in LeMay index $(\Delta \%$ LMI) at 24 hours. The 'normal' group showed a mean decrease in ventricular size of $1.2 \%$, and the patients with normal pressure hydrocephalus a mean increase of $3.7 \%$ (the difference between these two figures being highly significant). The results in the remaining groups were intermediate, their increase or small decrease in size being different from that of the 'normal' group only at a low level of significance. The relative differences between the groups in the series examined using local and general anaesthesia were similar. Thus, the ascending order of increase in size was: local anaesthesia A, B, E, C, and D, and general anaesthesia A, C, B, E, and D. Given that the technique of encephalography was almost identical except for the mode of anaesthesia, it is clear that the general tendency towards an overall increase in size of the ventricles after studies conducted using local anaesthesia is much less marked when the examination has been carried out under 
Table 2 Initial and 24 hour LeMay indices (LMI) under nitrous oxide anaesthesia

\begin{tabular}{|c|c|c|c|c|c|c|c|c|c|c|}
\hline Group & Number & $\begin{array}{l}\text { Mean } \\
\text { initial } \\
\text { LMI }\end{array}$ & Range & $S D$ & $\begin{array}{l}\text { Significance } \\
\text { of } \\
\text { difference } \\
\text { from } G p A\end{array}$ & $\begin{array}{l}\text { Mean } \Delta \% \\
\text { LMI }\end{array}$ & Range & & $S D$ & Significance \\
\hline $\begin{array}{l}\text { A } \\
\text { B } \\
\text { C } \\
\text { D } \\
\text { E }\end{array}$ & $\begin{array}{l}12 \\
14 \\
22 \\
18 \\
13\end{array}$ & $\begin{array}{l}0.277 \\
0.265 \\
0.343 \\
0.371 \\
0.321\end{array}$ & $\begin{array}{l}0.234-0.295 \\
0.183-0.292 \\
0.301-0.439 \\
0.275-0.448 \\
0.223-0.566\end{array}$ & $\begin{array}{l} \pm 0.019 \\
\pm 0.032 \\
\pm \mathbf{0 . 0 3 2} \\
\pm \mathbf{0 . 0 4 4} \\
\pm \mathbf{0 . 0 8 3}\end{array}$ & $\begin{array}{l}- \\
0.025 \\
0.001 \\
0.001 \\
0.05\end{array}$ & $\begin{array}{l}-1.2 \\
+0.1 \\
-0.1 \\
+3.7 \\
+0.6\end{array}$ & $\begin{array}{l}-4.4- \\
-3.1- \\
-7.6- \\
-1.1- \\
-4.6-\end{array}$ & $\begin{array}{l}+2.1 \\
+\quad 5.2 \\
+17.7 \\
+12.4 \\
+\quad 4.5\end{array}$ & $\begin{array}{l} \pm 1.9 \\
+1.4 \\
\pm 5.1 \\
\pm 3.0 \\
\pm 3.0\end{array}$ & $\begin{array}{l}\overline{0.05} \\
0.05 \\
0.001 \\
0.005\end{array}$ \\
\hline Total & 79 & 0.316 & $0.183-0.566$ & & & +0.7 & $-7.6-$ & +17.1 & \pm 4.1 & \\
\hline
\end{tabular}

general anaesthesia; these differences are highly significant (Table 3).

\section{EFFECTS OF VARIATION IN END-EXPIRED CO. CONCENTRATION}

The patient population and the effects of changes in end-expired $\mathrm{CO}_{2}$ percentage on the lateral ventricles are shown in Tables 4 and 5 ; the $\mathrm{CO}_{2}$ changes have been expressed as $\mathrm{PaCO}_{2}$ equivalents (see Discussion). Tables 6 and 7 show the changes produced in the cerebral sulci.

Patients in whom the $\mathrm{PaCO}_{2}$ was increased by a mean figure of approximately 15 torr showed no significant change in the size of the lateral ventricles. In no case was there an increase in size of more than $1.6 \%$, and only one patient (LH) showed a change which even partially reversed after restitution of the $\mathrm{CO}_{2}$ level to its original value.

The width of the sulci decreased with elevation of the $\mathrm{PaCO}_{2}$ in five of the seven cases in which measurements were possible, and in three of these it subsequently increased when the $\mathrm{PaCO}_{2}$ was lowered (Fig. 1). The responses to changes in $\mathrm{PaCO}_{2}$ were, however, rather variable, and as a result the overall figures are not statistically significant.

Patients in whom the $\mathrm{PaCO}$, was initially lowered also showed little or no change in ventricular size as a result of a mean fall in $\mathrm{PaCO}$, of approximately 12 torr (Fig. 2). Measurement of the sulci was possible in two of the three cases, and although both of these showed an increase in the diameter of the sulci, which reversed when the $\mathrm{PaCO}_{2}$ was restored to its original level, the small number of observations are of necessity without statistical significance.

EFFECTS OF NITROUS OXIDE INHALATION

Lateral ventricles (Fig. 3) In all but two cases there was an increase in size of the lateral ventricles after addition of nitrous oxide to the inhaled gas mixture, although in no case did the increase exceed $5.5 \%$, and, with the exception of the two cases measured at about 20 minutes (which were already the two cases showing the greatest increase in size), the results did not attain statistical significance (Table 8).

Six of the 10 cases showed a small decrease (maximum $7.0 \%$ ) in the size of the lateral ventricles after withdrawal of nitrous oxide from the inhaled gases. Again, the results were significant only at a low level (Table 9).

Third ventricle (Fig. 4) There was an increase in size of the third ventricle with nitrous oxide inhalation in eight of the 10 cases, by as much as $42.9 \%$. One of the two cases not showing enlargement of the lateral ventricles also failed to show an increase in size of the third ventricle, but the third ventricle of the other similar case enlarged in transverse diameter by $19.0 \%$. There was a wide spread of responses, and particularly of initial

Table 3 Percentage changes in LeMay index ( $\%$ LMI) at 24 hours after pneumoencephalography under general and local anaesthesia

\begin{tabular}{|c|c|c|c|c|c|c|c|c|c|c|c|}
\hline \multirow[b]{2}{*}{ Group } & \multicolumn{5}{|c|}{ General anaesthesia with nitrous oxide } & \multicolumn{5}{|c|}{ Local anaesthesia } & \multirow[b]{2}{*}{$\begin{array}{l}\text { Significance } \\
\text { of difference } \\
\text { (i)-(ii) }\end{array}$} \\
\hline & Number & $\begin{array}{l}\text { Mean } \\
\Delta \% \\
L M I(i)\end{array}$ & Range & & $S D$ & Number & $\begin{array}{l}\text { Mean } \\
4 \% \\
L M I(i i)\end{array}$ & Range & & $S D$ & \\
\hline $\begin{array}{l}\text { A } \\
\text { B } \\
\text { C } \\
\text { D } \\
\text { E }\end{array}$ & $\begin{array}{l}12 \\
14 \\
22 \\
18 \\
13\end{array}$ & $\begin{array}{r}-1.2 \\
+0.1 \\
-0.1 \\
+3.7 \\
+0.6\end{array}$ & $\begin{array}{l}-4.4- \\
-3.1- \\
-7.6- \\
-1.1- \\
-4.6-\end{array}$ & $\begin{array}{r}+2.1 \\
+\quad 5.2 \\
+17.1 \\
+12.4 \\
+\quad 4.5\end{array}$ & $\begin{array}{l}+1.9 \\
+3.5 \\
+5.2 \\
+3.3 \\
+3.0\end{array}$ & $\begin{array}{l}27 \\
33 \\
37 \\
23 \\
30\end{array}$ & $\begin{array}{r}+9.8 \\
+2.9 \\
+4.3 \\
+8.4 \\
+2.9\end{array}$ & $\begin{array}{l}-4.1- \\
-5.9- \\
-1.2- \\
-0.6- \\
-6.1-\end{array}$ & $\begin{array}{r}+6.4 \\
+10.4 \\
+12.6 \\
+22.8 \\
+\quad 8.4\end{array}$ & $\begin{array}{l}+2.3 \\
+4.0 \\
\pm 3.7 \\
\pm 5.8 \\
+3.6\end{array}$ & $\begin{array}{l}0.0125 \\
0.001 \\
0.001 \\
0.0025 \\
0.005\end{array}$ \\
\hline Total & 79 & 0.7 & $-7.6-$ & +17.1 & +4.1 & 150 & +3.6 & $-6.1-$ & +22.8 & +3.9 & 0.001 \\
\hline
\end{tabular}



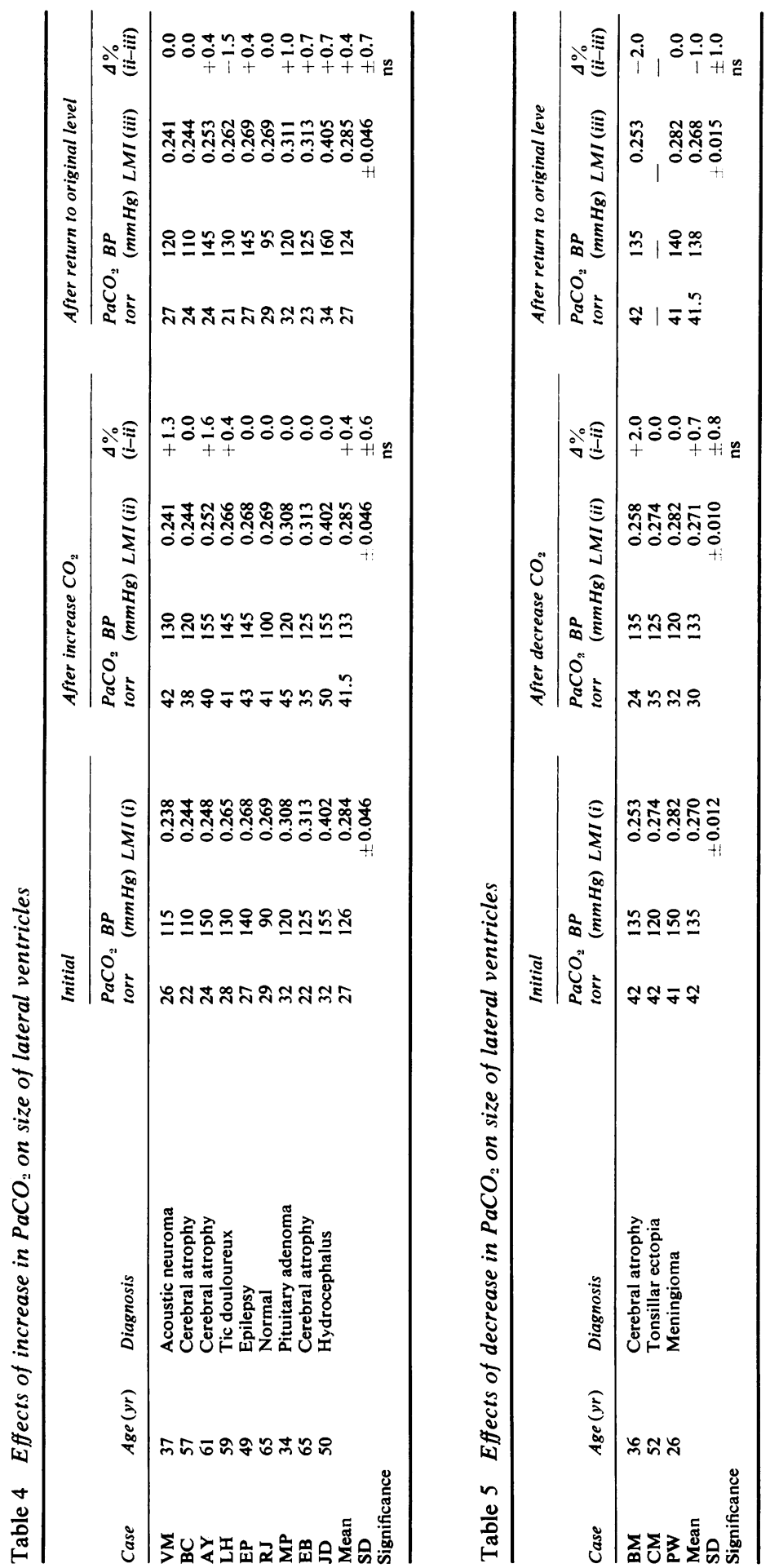
Table 6 Effects of increase in PaCO on size of cerebral sulci

\begin{tabular}{|c|c|c|c|c|c|c|c|c|c|c|c|}
\hline Case & $\begin{array}{l}\mathrm{PaCO}_{2} \\
\text { (i) torr }\end{array}$ & $\begin{array}{l}B P \\
(m m H g)\end{array}$ & $\begin{array}{l}\text { Mean sulcus } \\
\text { diameter } \\
(\mathrm{mm}) \\
A\end{array}$ & $\begin{array}{l}\mathrm{PaCO}_{2} \\
\text { (ii) torr }\end{array}$ & $\begin{array}{l}B P \\
(m m H g)\end{array}$ & $\begin{array}{l}\text { Mean sulcus } \\
\text { diameter } \\
(\mathrm{mm}) \\
B\end{array}$ & $\begin{array}{l}\Delta \% \\
A-B\end{array}$ & $\begin{array}{l}\mathrm{PaCO}_{2} \\
\text { (iii) torr }\end{array}$ & $\begin{array}{l}B P \\
(m m H g)\end{array}$ & $\begin{array}{l}\text { Mean sulcus } \\
\text { diameter } \\
(\mathrm{mm}) \\
\mathrm{C}\end{array}$ & $\begin{array}{l}\Delta \% \\
B-C\end{array}$ \\
\hline VM & 26 & 115 & 1.40 & 42 & 130 & 1.63 & -16.4 & 27 & 120 & 1.55 & -4.9 \\
\hline BC & 22 & 110 & 1.42 & 38 & 120 & 1.32 & -7.0 & 24 & 110 & 1.08 & -12.1 \\
\hline AY & 24 & 150 & 3.82 & 40 & 155 & 3.70 & -3.1 & 24 & 145 & 3.80 & +2.7 \\
\hline EP & 27 & 140 & 1.54 & 43 & 145 & 1.58 & $\therefore \quad 2.6$ & 27 & 145 & 1.34 & -15.2 \\
\hline MP & 32 & 120 & 2.86 & 45 & 120 & 2.61 & -8.7 & 32 & 120 & 2.56 & -19.1 \\
\hline EB & 22 & 125 & 2.25 & 35 & 125 & 1.90 & -14.9 & 23 & 125 & 2.75 & -44.7 \\
\hline Mean & 26 & 121 & 2.01 & 40.5 & 128 & 1.93 & -2.7 & 26.5 & 123 & 2.01 & +2.6 \\
\hline SD & & & $\therefore 0.96$ & & & $\begin{array}{l}\quad 0.89 \\
-\quad 0\end{array}$ & \pm 9.3 & & & +0.89 & $\div 15.9$ \\
\hline \multicolumn{6}{|c|}{ Significance $\mathbf{P}=$} & 0.35 & & & & 0.45 & \\
\hline
\end{tabular}

Table 7 Effects of decrease in $\mathrm{PaCO}_{2}$ on size of cerebral sulci

\begin{tabular}{|c|c|c|c|c|c|c|c|c|c|c|c|}
\hline Case & $\begin{array}{l}\mathrm{PaCO}_{2} \\
\text { (i) torr }\end{array}$ & $\begin{array}{l}B P \\
(m m H g)\end{array}$ & $\begin{array}{l}\text { Mean sulcus } \\
\text { diameter } \\
(\mathrm{mm})\end{array}$ & $\begin{array}{l}\mathrm{PaCO}_{2} \\
\text { (ii) torr }\end{array}$ & $\begin{array}{l}B P \\
(m m H g)\end{array}$ & $\begin{array}{l}\text { Mean sulcus } \\
\text { diameter } \\
(\mathrm{mm})\end{array}$ & $\begin{array}{l}\Delta \% \\
A-B\end{array}$ & $\begin{array}{l}\mathrm{PaCO}_{2} \\
\text { (iii) torr }\end{array}$ & $\begin{array}{l}B P \\
(m m H g)\end{array}$ & $\begin{array}{l}\text { Mean sulcus } \\
\text { diameter } \\
(\mathrm{mm})\end{array}$ & $\begin{array}{l}\Delta \% \\
B-C\end{array}$ \\
\hline $\begin{array}{l}\text { BM } \\
\text { PW } \\
\text { Mean } \\
\text { SD } \\
\text { Significance }\end{array}$ & $\begin{array}{l}42 \\
41 \\
41.5 \\
\text { e } P=\end{array}$ & $\begin{array}{l}135 \\
150 \\
143\end{array}$ & $\begin{aligned} & 2.67 \\
& 0.73 \\
& 1.70 \\
\therefore & 1.0\end{aligned}$ & $\begin{array}{l}24 \\
32 \\
28\end{array}$ & $\begin{array}{l}135 \\
140 \\
138\end{array}$ & $\begin{array}{r}3.10 \\
0.76 \\
1.93 \\
+1.43\end{array}$ & $\begin{array}{l}+16.1 \\
+\quad 3.9 \\
+\quad 7.9 \\
+\quad 6.5 \\
\quad 0.45\end{array}$ & $\begin{array}{l}42 \\
41 \\
41.5\end{array}$ & $\begin{array}{l}135 \\
140 \\
138\end{array}$ & $\begin{array}{r}2.97 \\
0.58 \\
1.78 \\
+1.77\end{array}$ & $\begin{array}{l}-4.2 \\
-23.7 \\
-17.2 \\
=10.3 \\
\quad 0.35\end{array}$ \\
\hline
\end{tabular}

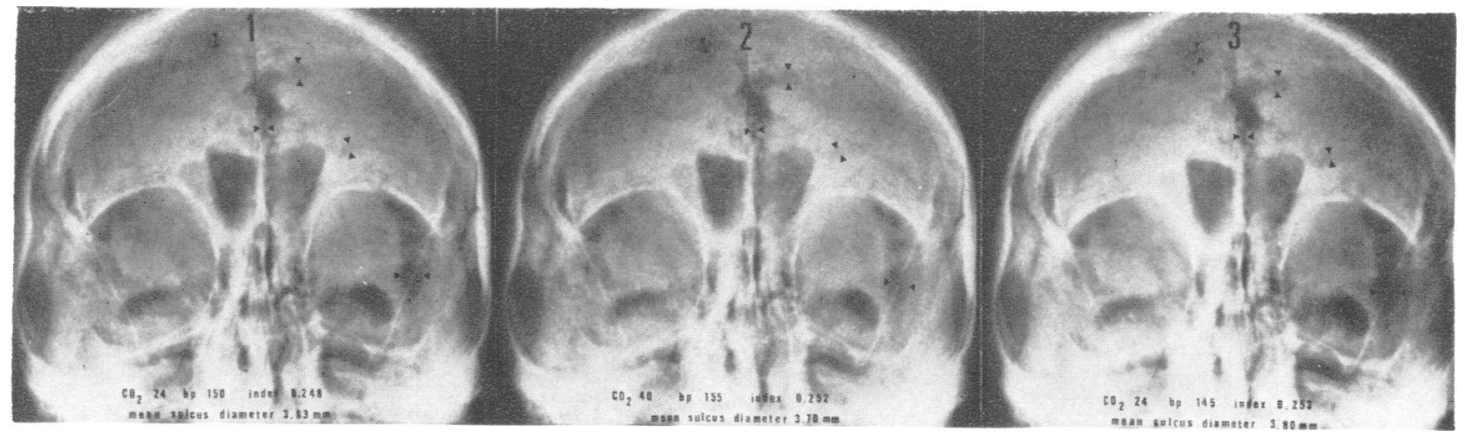

Fig. 1 Effects of increase of PaCO: on cerebral ventricles and sulci. 1. PaCO:=24 torr. LeMay index (LMI) 0.248 . Mean diameter of sulci indicated by arrowheads $3.83 \mathrm{~mm}$. 2. PaCO : 40 torr. LMI: $0.252(\Delta \%=1.6)$. Mean sulcus dianeter $3.70 \mathrm{~mm}(\Delta \%=-3.1)$. 3. PaCO: 24 torr. LMI: $0.53(\Delta \%+0.4)$. Mean sulcus diameter $3.80 \mathrm{~mm}(\Delta \%=+2.7)$.

third ventricular size, however, and the results were, therefore, not statistically significant (Table 10).

When nitrous oxide inhalation was discontinued, the responses were more variable, but five cases showed a definite sustained decrease in size; the spread of the results once again rendered them non-significant (Table 11).

Some patients showed a progressive increase or decrease in size of the lateral or third ventricles over the period of observation, but this was not universal, being seen in only 12 out of 40 series of films. The responses of the lateral and third ventricles of any given patient to addition or withdrawal of nitrous oxide were also not invariably identical.

The ventricles of the 'experimental' (air/nitrous oxide/air) group showed a further small increase in size from the initial series of films to the final series, whereas the 'control' (nitrous oxide throughout) group had slightly smaller ventricles at the end of the examination (Table 12). Although the results did not achieve a high level of significance, they suggest a progression of ventricular enlargement in the 'experimental' group. The volume of gas injected and time elapsed between the two sets of radiographs was similar in the two groups. There was no gas in the third ventricles of half the patients in the 'control' group at the end of the examination. 


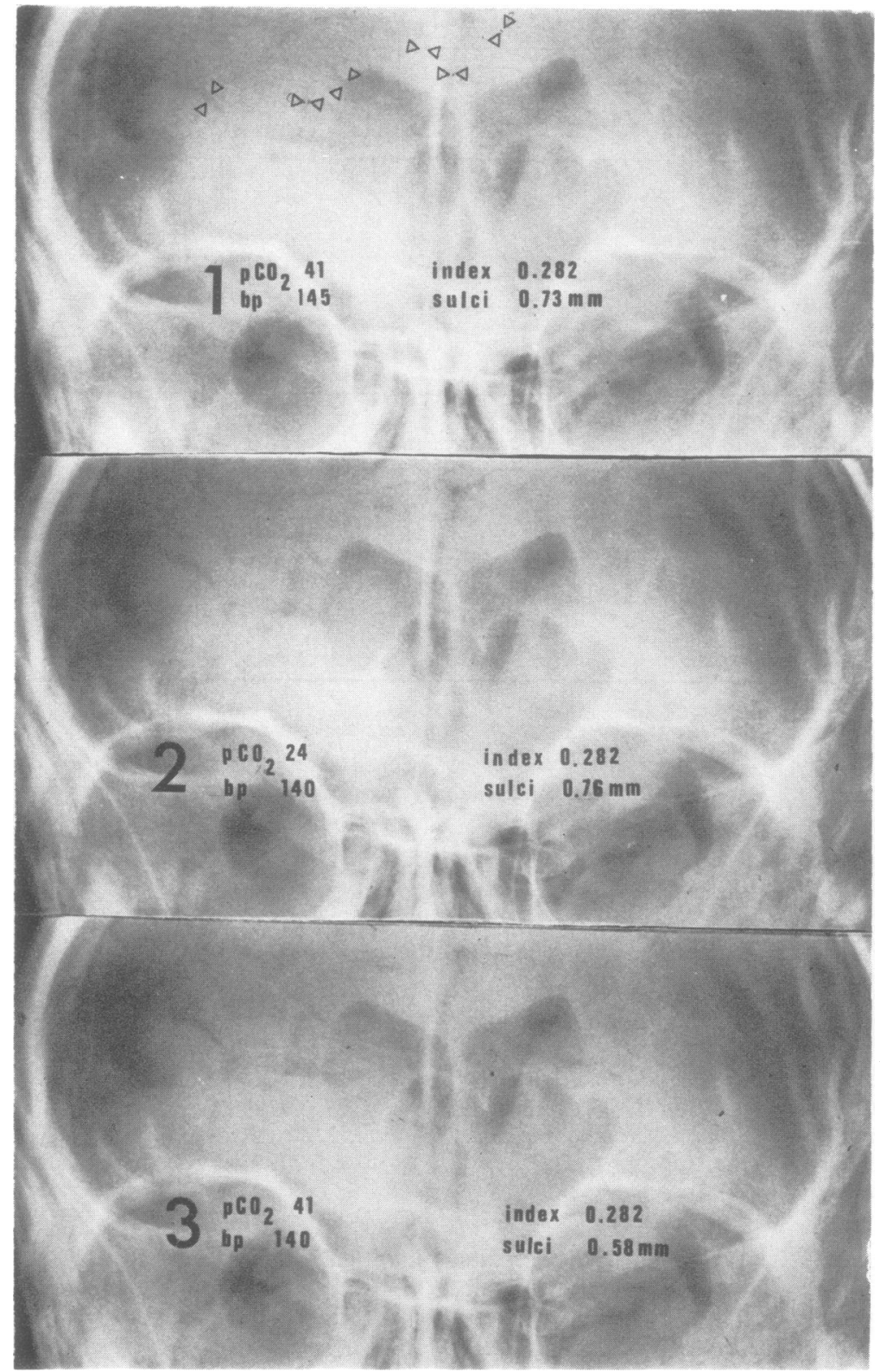

Fig. 2 Effects of decrease of $\mathrm{PaCO}_{2}$ on ventricles and sulci. 1. $\mathrm{PaCO}$ : 41 torr. LMI 0.282. Mean sulcus diameter: $0.73 \mathrm{~mm}$. 2. PaCO $: 32$ torr. LMI: $0.282(\Delta \%=0)$. Mean sulcus diameter: $0.76 \mathrm{~mm}(\triangle \%=3.9)$. 3. $\mathrm{PaCO}_{2}$ : 41 torr. $L M I 0.282(\Delta \%=0)$. Mean sulcus diameter: $0.58 \mathrm{~mm}(\Delta \%=-23.7)$.

Sulci (Figs. 5 and 6) It was possible to measure the width of the sulci in seven cases. Six of these showed an apparent increase in the size of the sulci after the introduction of nitrous oxide, al- though in one case this was not sustained (Table 13). In the other five, the enlargement was progressive; the maximum increase was $63.6 \%$, after 21 minutes of exposure to nitrous oxide. 


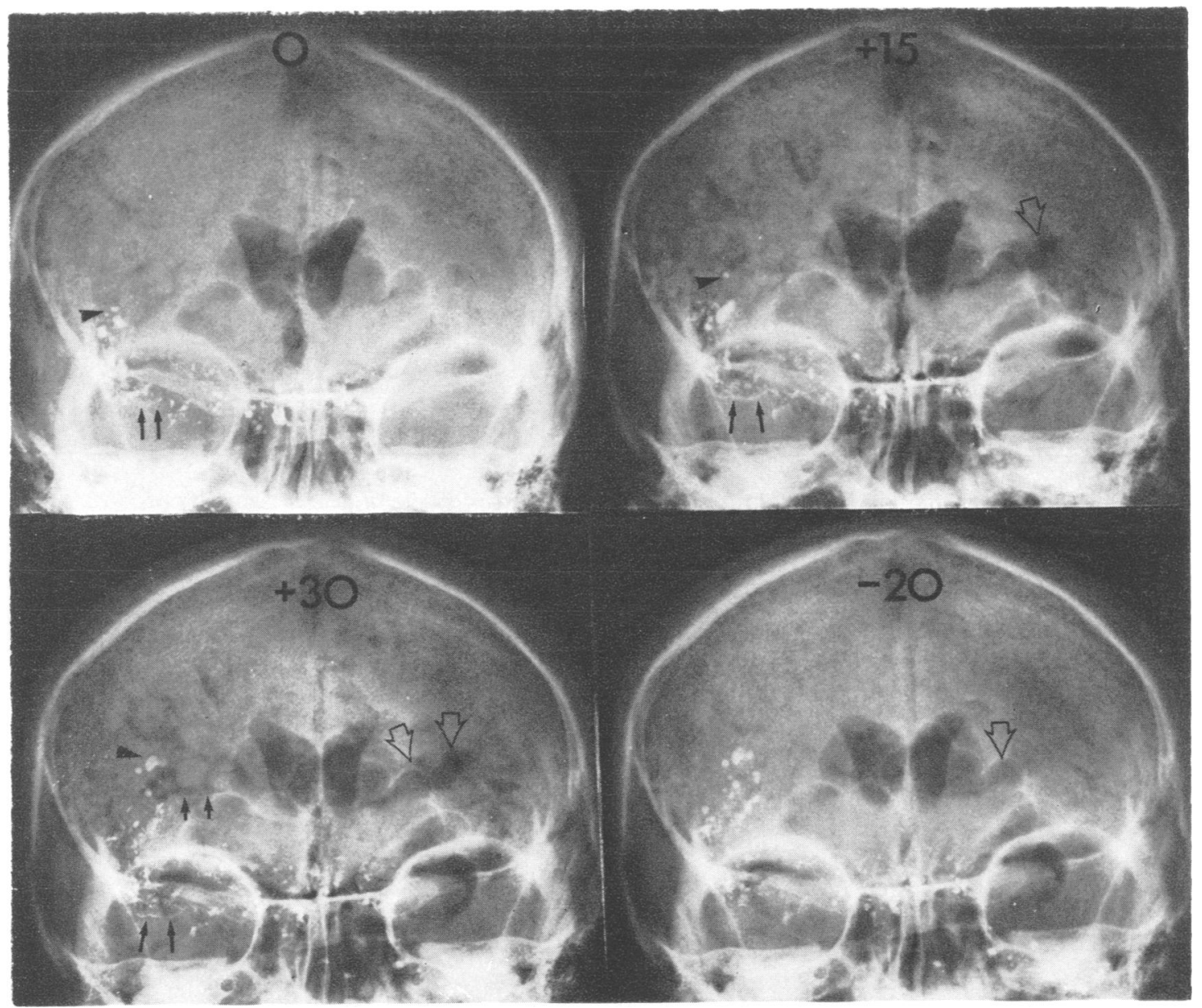

Fig. 3 Effects of exposure to nitrous oxide. Figures at top of each radiograph indicate minutes of exposure. Initial film (0): LeMay index: (LMI) 0.272. Note iophendylate (Myodil) in Sylvian fissure (arrows) and high over insula (arrowhead). $+15: L M I=0.277(\Delta \%=+1.8)$. Note increased prominence of frontal sulci eg on left (open arrow). The lower Myodil now outlines gas bubble (arrows), while the uppermost droplet has moved further distally. +30 (after somersault): LMI: $0.280(\Delta \%=+2.9)$. Sulci are very prominent, and there is a large gas bubble in the lower Sylvian fissure on right (arrows). Note sulci indicated by two small and two open arrows. Further sulci indicated by two small and two open arrows. Further migration of the Myodil (arrowhead). -20: (20 minutes after cessation of nitrous oxide) LMI: $0.275(\Delta \%=-1.8)$. Most sulci are no longer visible $(c f+30)$.

A difficulty encountered after discontinuation of nitrous oxide inhalation was that the quantity of gas in the sulci decreased so rapidly that it became impossible to measure an acceptable number of sulci in more than six patients, and even in these, only one set of measurements could be made after 10 minutes (Table 14). However, four of the cases showed an apparent decrease in size of the sulci, which was progressive, up to $33.3 \%$ of the maximum diameter.

\section{Discuszion}

COMPARISON OF CHANGES IN VENTRICULAR SIZE AFTER PNEUMOENCEPHALOGRAPHY USING GENERAL AND LOCAL ANAESTHESIA

Unfortunately, most published reports on serial changes in ventricular size do not include any indication of the mode of anaesthesia used. It is highly probable that most of the earlier series, especially those including children, concern groups 
Table 8 Effects of addition of nitrous oxide to inhaled gases on size of lateral ventricles

\begin{tabular}{|c|c|c|c|c|c|c|c|c|c|c|c|}
\hline \multirow[b]{3}{*}{ Patient } & \multirow[b]{3}{*}{ Diagnosis } & \multirow{3}{*}{$\begin{array}{l}\text { Volume } \\
\text { air }(m l)\end{array}$} & \multirow{3}{*}{$\begin{array}{l}\text { Initial } \\
L M I\end{array}$} & \multicolumn{8}{|c|}{ After addition of nitrous oxide } \\
\hline & & & & \multicolumn{2}{|l|}{$5 \min$} & \multicolumn{2}{|c|}{$6-10 \mathrm{~min}$} & \multicolumn{2}{|c|}{$11-15 \min$} & \multicolumn{2}{|l|}{$15 \min$} \\
\hline & & & & $L M I$ & $\Delta \%$ & $L M I$ & $\Delta \%$ & $L M I$ & $\Delta \%$ & $L M I$ & $\Delta \%$ \\
\hline EA & Multiple sclerosis & 45 & 0.228 & 0.231 & +1.3 & 0.231 & +1.3 & 0.231 & +1.3 & - & - \\
\hline IH & Cerebral atrophy & 35 & 0.238 & 0.240 & +0.8 & p.234 & +2.1 & - & - & - & - \\
\hline MS & Infratentorial tumour & 35 & 0.239 & 0.238 & 0.0 & 0.240 & +0.8 & 0.240 & +0.8 & - & - \\
\hline $\mathbf{A G}$ & Temporal tumour & 35 & 0.258 & 0.250 & -3.1 & 0.247 & -4.3 & 0.250 & -3.1 & - & - \\
\hline HR & Acoustic neuroma & 30 & 0.272 & 0.272 & 0.0 & 0.280 & +2.9 & 0.277 & +1.8 & 0.283 & +4.0 \\
\hline DH & Pontine glioma & 35 & 0.277 & 0.281 & +1.4 & 0.281 & +1.4 & 0.292 & +5.4 & 0.287 & +3.6 \\
\hline FD & Pontine glioma & 35 & 0.281 & 0.284 & +1.1 & 0.278 & -1.1 & - & - & - & - \\
\hline GS & Pituitary adenoma & 40 & 0.311 & 0.317 & +1.9 & 0.317 & +1.9 & 0.317 & +1.9 & - & - \\
\hline CB & Pinealoma & 40 & 0.329 & 0.329 & 0.0 & 0.329 & 0.0 & 0.326 & -0.9 & 一 & - \\
\hline LJ & Meningioma & 40 & 0.329 & 0.329 & 0.0 & 0.331 & +0.6 & - & - & - & - \\
\hline & 37 & 0.276 & 0.277 & +0.3 & 0.278 & +0.6 & 0.276 & +1.0 & 0.285 & +3.8 \\
\hline \multirow{2}{*}{\multicolumn{2}{|c|}{$\begin{array}{l}\text { SD } \\
\text { Significance } P=\end{array}$}} & & $\pm \mathbf{0 . 0 3 5}$ & \pm 0.036 & \pm 1.3 & $\pm \mathbf{0 . 0 3 6}$ & \pm 1.9 & $\pm \mathbf{0 . 0 3 5}$ & \pm 2.0 & \pm 0.002 & \pm 0.2 \\
\hline & & & & & n.s. & & n.s. & & n.s. & & 0.01 \\
\hline
\end{tabular}

Table 9 Effects of withdrawal of nitrous oxide from inhaled gases on size of lateral ventricles

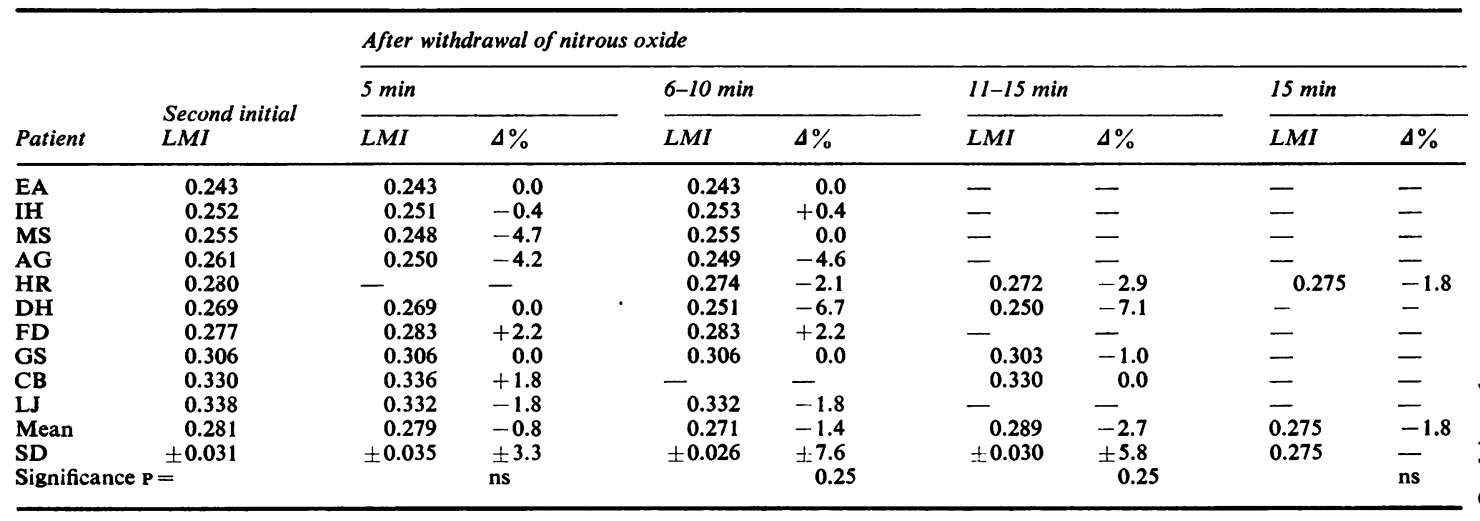

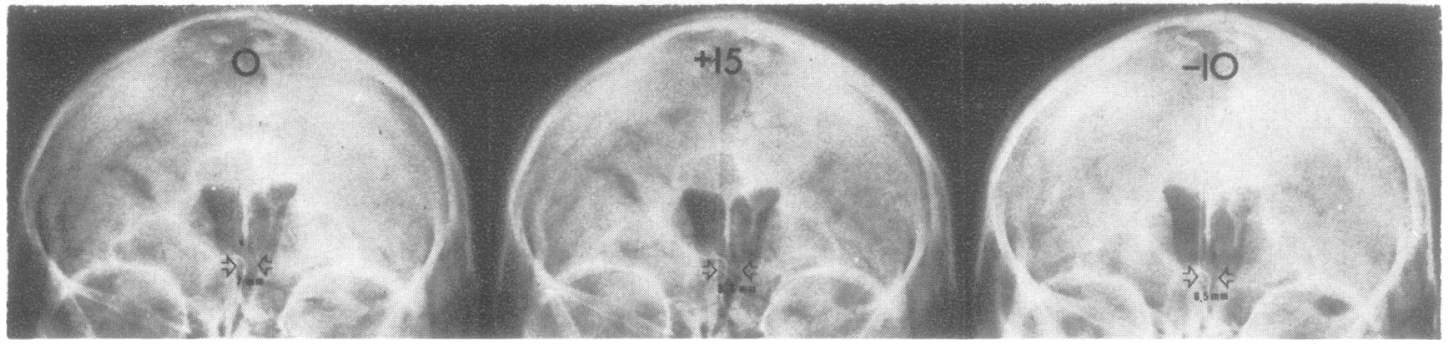

Fig. 4 Effects of exposure to nitrous oxide. Labels as Fig. 3. Initial film: third ventricular index (TVI): 0.040. +15: TVI: 0.052. $(\Delta \%=+30 \cdot 9)$. Note prominent sulci. $-10:$ TVI: $0.038(\Delta \%=-19.1)$. Sulci are almost invisible.

of patients studied using both local and general anaesthesia. Nevertheless, it has been clear for many years that the diagnostic results of the procedure might be modified by the anaesthetic technique. Thus, Davidoff and Dyke (1937) found that the incidence of non-filling of the cerebral ventricles rose from $6 \%$ when the examination was conducted using local anaesthesia to $12.4 \%$ when general anaesthesia (usually produced by ether) was used. This was confirmed in a series of 1000 consecutive cases by Bohn (1937), who gave figures of $7.4 \%$ and $16 \%$ respectively. The experience of later workers was similar, showing that inhalation anaesthetics could modify the radiographic appearances (Ghersi et al., 1947). Bohn's findings that the effects on ventricular filling could be 
Table 10 Effects of addition of nitrous oxide to inhaled gases on size of third ventricle

\begin{tabular}{|c|c|c|c|c|c|c|c|c|c|}
\hline \multirow[b]{3}{*}{ Patient } & \multirow{3}{*}{$\begin{array}{l}\text { Initial } \\
T V I\end{array}$} & \multicolumn{8}{|c|}{ After addition of nitrous oxide } \\
\hline & & \multicolumn{2}{|l|}{$5 \min$} & \multicolumn{2}{|c|}{$6-10 \min$} & \multicolumn{2}{|c|}{$11-15 \mathrm{~min}$} & \multicolumn{2}{|c|}{$15 \min$} \\
\hline & & $T V I$ & $\Delta \%$ & $T V I$ & $\Delta \%$ & $T V I$ & $\Delta \%$ & $T V I$ & $\Delta \%$ \\
\hline EA & 0.040 & 0.046 & +15.0 & 0.052 & +30.0 & 0.052 & +30.0 & - & - \\
\hline $\mathrm{IH}$ & 0.027 & 0.030 & +11.1 & 0.030 & +11.1 & - & - & - & - \\
\hline MS & 0.047 & 0.047 & 0.0 & 0.049 & +4.3 & 0.049 & +4.3 & - & - \\
\hline AG & 0.058 & 0.052 & -10.3 & 0.052 & -10.3 & 0.055 & -5.2 & - & - \\
\hline HR & 0.040 & 0.035 & -12.5 & 0.035 & -12.5 & 0.035 & -12.5 & 0.035 & -12.5 \\
\hline DH & 0.061 & 0.066 & +8.2 & 0.070 & +14.8 & 0.074 & +21.3 & - & - \\
\hline FD & 0.060 & 0.063 & +5.0 & 0.063 & +5.0 & - & - & - & - \\
\hline GS & 0.021 & 0.030 & +42.9 & 0.030 & +42.9 & 0.030 & +42.9 & - & - \\
\hline CB & 0.063 & 0.063 & 0.0 & 0.075 & +19.0 & 0.075 & +19.0 & - & - \\
\hline LJ & 0.054 & 0.057 & +5.5 & 0.063 & +16.7 & 一 & - & - & - \\
\hline Mean & 0.047 & 0.049 & +6.5 & 0.052 & +12.1 & 0.054 & +14.3 & 0.035 & -12.5 \\
\hline SD & \pm 0.019 & \pm 0.013 & \pm 14.7 & \pm 0.018 & \pm 16.0 & \pm 0.016 & \pm 18.3 & - & -- \\
\hline
\end{tabular}

Table 11 Effects of withdrawal of nitrous oxide from inhaled gases on size of third ventricle

\begin{tabular}{|c|c|c|c|c|c|c|c|c|c|}
\hline \multirow[b]{3}{*}{ Patient } & \multirow{3}{*}{$\begin{array}{l}\text { Second initial } \\
T V I\end{array}$} & \multicolumn{8}{|c|}{ After withdrawal of nitrous oxide } \\
\hline & & \multicolumn{2}{|l|}{$5 \min$} & \multicolumn{2}{|c|}{$6-10 \mathrm{~min}$} & \multicolumn{2}{|c|}{$11-15 \mathrm{~min}$} & \multicolumn{2}{|l|}{$15 \mathrm{~min}$} \\
\hline & & $T V I$ & $\Delta \%$ & $T V I$ & $\Delta \%$ & $T V I$ & $\Delta \%$ & $T V I$ & $\Delta \%$ \\
\hline EA & 0.047 & 0.043 & -8.5 & 0.038 & -19.1 & - & - & - & - \\
\hline IH & 0.030 & 0.030 & 0.0 & 0.027 & -10.0 & - & - & - & - \\
\hline MS & 0.036 & 0.036 & 0.0 & 0.036 & 0.0 & - & - & - & - \\
\hline $\mathrm{AG}$ & 0.044 & 0.042 & -4.5 & 0.036 & -18.2 & 0.036 & -18.2 & - & - \\
\hline HR & 0.029 & 0.026 & -10.3 & 0.040 & $\begin{array}{r}37.9 \\
+37\end{array}$ & 0.038 & +34.2 & 0.021 & -27.6 \\
\hline $\mathrm{DH}$ & 0.068 & 0.068 & 0.0 & 0.063 & -8.1 & 0.057 & -16.2 & - & - \\
\hline FD & 0.052 & 0.055 & +5.8 & 0.052 & 0.0 & - & - & 一 & - \\
\hline GS & 0.027 & 0.024 & -11.1 & - & - & 0.030 & +11.1 & - & - \\
\hline $\mathrm{CB}$ & 0.070 & 0.076 & +7.9 & 0.076 & +7.9 & - & - & - & - \\
\hline LJ & 0.077 & 0.065 & -14.2 & 0.051 & -33.8 & - & - & - & - \\
\hline Mean & 0.048 & 0.047 & -3.5 & 0.047 & -4.8 & 0.040 & +3.7 & 0.021 & -27.6 \\
\hline SD & \pm 0.017 & \pm 0.018 & \pm 7.1 & \pm 0.015 & \pm 19.1 & \pm 0.010 & \pm 25.5 & - & - \\
\hline
\end{tabular}

lessened by an intravenous infusion of hypertonic dextrose suggested that they were due at least in part to brain swelling.

Logical explanations for the highly significant difference in post-encephalographic changes in ventricular size observed between the present study and that of Moseley and Sondheimer (1975) must include consideration of the following possibilities.

A. That when general anaesthesia is used:

(i) during anaesthesia either (a) the brain shrinks or (b) the ventricles increase in size, or both occur;

(ii) after the anaesthetic (a) the brain swells or (b) the ventricles become smaller, or both occur.

B. That when local anaesthesia is used:

(i) during pneumoencephalography (a) the brain swells or (b) the ventricles collapse, or both occur;

(ii) after encephalography (a) the ventricles expand or (b) the brain shrinks, or both occur.

Data are available concerning some of these suggestions, and others may be considered from the theoretical viewpoint.

Reduction of cerebral volume under general anaesthesia

Several groups of workers have noted that general anaesthesia tends to favour non-filling of the ventricles at encephalography, and Bohn (1937) showed that this could be counteracted by an osmotic diuresis. Reduced cerebral volume as a result of general anaesthesia per se, therefore, seems unlikely; furthermore, it has been shown that changes occur suggesting increased cerebral blood flow and volume during general anaesthesia (McDowall et al., 1966), while pneumoencephalography under local anaesthesia reduces cerebral blood volume (Voigt and Greitz, 1976).

It has been suggested that shrinkage of the brain may occur when patients are hyperventilated during pneumoencephalography (Bernini et al., 1973), and, if correct, this would be in agreement with the considerable reduction in cerebral blood flow and volume which McHenry et al. (1965) showed to occur after only a few minutes of vol- 
Table 12 'Interval change' in size of lateral and third ventricles in patients breathing air/nitrous oxide/air compared with that of patients breathing nitrous oxide throughout

\begin{tabular}{|c|c|c|c|c|c|c|c|c|}
\hline \multirow[b]{2}{*}{ Patient } & \multirow{2}{*}{$\begin{array}{l}\text { Volume } \\
\operatorname{air}(\mathrm{ml})\end{array}$} & \multicolumn{2}{|l|}{ Initial } & \multirow[b]{2}{*}{ Time $(\min )$} & \multicolumn{4}{|l|}{ Final } \\
\hline & & $L M I$ & $T V I$ & & $L M I$ & $\Delta \%$ & $T V I$ & $\Delta \%$ \\
\hline \multicolumn{9}{|c|}{ Air/nitrous oxide/air } \\
\hline EA & 45 & 0.228 & 0.040 & 45 & 0.243 & +6.6 & 0.047 & +17.5 \\
\hline IH & 35 & 0.238 & 0.027 & 35 & 0.252 & $\begin{array}{r}1.0 \\
+\quad 5.9\end{array}$ & 0.030 & +11.1 \\
\hline MS & 35 & 0.238 & 0.047 & 30 & 0.255 & +7.1 & 0.036 & -23.4 \\
\hline $\mathbf{A G}$ & 35 & 0.258 & 0.058 & 50 & 0.261 & +1.2 & 0.044 & -24.1 \\
\hline HR & 30 & 0.270 & 0.040 & 30 & 0.280 & $\begin{array}{r}1.9 \\
+2.9\end{array}$ & 0.029 & -27.5 \\
\hline DH & 35 & 0.277 & 0.061 & 55 & 0.269 & -2.9 & 0.068 & +11.4 \\
\hline FD & 35 & 0.281 & 0.060 & 30 & 0.277 & -1.4 & 0.052 & -13.3 \\
\hline GS & 40 & 0.311 & 0.021 & 50 & 0.306 & -1.6 & 0.027 & +22.2 \\
\hline CB & 40 & 0.329 & 0.063 & 35 & 0.330 & +0.3 & 0.070 & +11.1 \\
\hline LJ & 40 & 0.329 & 0.054 & 55 & 0.338 & +2.7 & 0.077 & +42.6 \\
\hline Mean & 37 & 0.276 & 0.047 & 44 & 0.281 & +2.0 & 0.048 & +2.8 \\
\hline SD & & \pm 0.035 & \pm 0.014 & & \pm 0.031 & \pm 2.6 & \pm 0.018 & \pm 22.3 \\
\hline \multicolumn{9}{|c|}{ Nitrous oxide throughout } \\
\hline RS & 32 & 0.227 & - & 90 & 0.237 & +4.4 & - & - \\
\hline JC & 25 & 0.256 & 0.036 & 35 & 0.251 & -2.0 & 0.043 & -23.2 \\
\hline CR & 50 & 0.281 & - & 90 & 0.294 & +4.6 & - & - \\
\hline HR & 30 & 0.282 & 0.061 & 60 & 0.284 & +0.7 & 0.060 & -1.2 \\
\hline JG & 40 & 0.292 & - & 50 & 0.292 & 0.0 & - & -1.2 \\
\hline JF & 30 & 0.293 & 0.049 & 60 & 0.301 & +2.7 & 0.043 & -12.2 \\
\hline SR & 40 & 0.295 & 0.037 & 60 & 0.294 & -0.3 & 0.037 & -35.1 \\
\hline AQ & 30 & 0.298 & - & 55 & 0.297 & -0.7 & - & - \\
\hline GB & 40 & 0.305 & 0.030 & 30 & 0.248 & -18.7 & 0.030 & 0.0 \\
\hline HB & 50 & 0.305 & - & 15 & 0.300 & -1.6 & - & -0.0 \\
\hline Mean & 37 & 0.283 & 0.047 & 54 & 0.280 & -1.1 & 0.043 & -14.3 \\
\hline \multicolumn{2}{|c|}{ SD } & $\pm \mathbf{0 . 0 2 4}$ & \pm 0.012 & & \pm 0.023 & 1. 6.3 & \pm 0.010 & \pm 13.3 \\
\hline \multicolumn{2}{|c|}{ Significance $\mathbf{P}=$} & ns & ns & & ns & 0.25 & ns & 0.1 \\
\hline
\end{tabular}

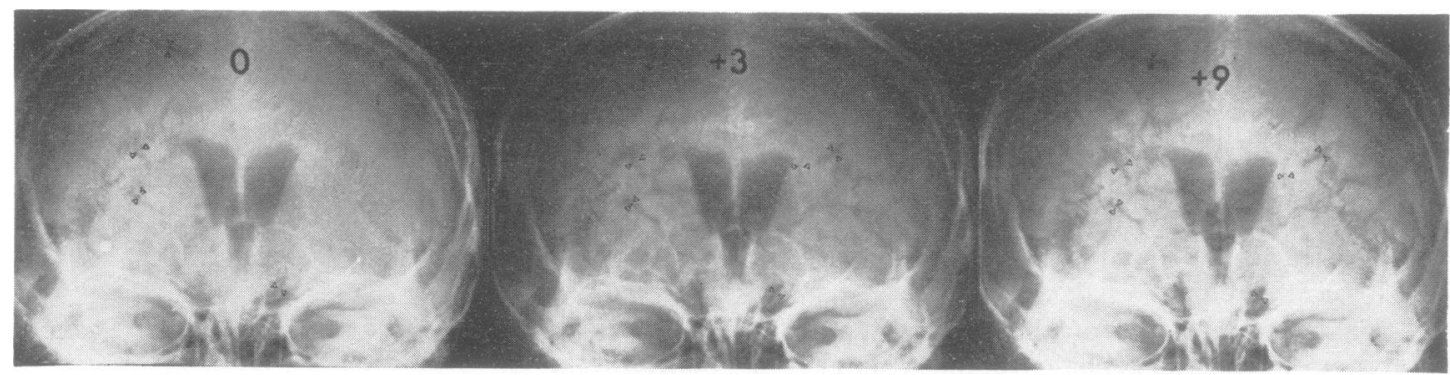

Fig. 5 Effects of exposure to nitrous oxide. Labels as Fig. 3. Initial film: mean sulcus diameter: $1.66 \mathrm{~mm}$. +3: mean sulcus diameter: $1.70 \mathrm{~mm}(\Delta \%=+2.4)$; far more sulci are filled but only sulci which were visible on the original film can be used for comparison. +9 : mean sulcus diameter: $1.69 \mathrm{~mm}(\Delta \%=+1.8)$.

untary hyperventilation. The work of Bernini et $a l$. is not, however, beyond fundamental criticism. They reported a series of 15 patients with intracranial tumours (two-thirds of them infratentorial) in whom pneumoencephalography under anaesthesia with droperidol and dextromoramide gave 'unsatisfactory results'. The pneumoencephalograms were repeated, preceded by 30 minutes controlled hyperventilation such that the $\mathrm{PaCO}_{2}$ was below 25 torr. Twelve of the patients then showed either complete or 'greatly improved' filling of the ventricles and subarachnoid spaces; a similar result was obtained in a 'normal' patient in whom the ventricles had previously failed to fill. In a separa:e study, nine 'normal' patients were similarly hyperventilated for periods of up to one hour after the completion of an encephalogram. The frontal horns were said to increase in diameter by from 2 to $4 \mathrm{~mm}$, but no details of the time course or spread of the results were given. From the one example illustrated in the original report it is by no means clear what measurements of the ventricles were being used, or how reproducible they were. It is also unclear whether the patients had been breathing spontaneously before the start of hyperventilation; it is possible that as a result of the initial anaesthesia they may have been markedly hypercapnoeic or hypoxic or both. The roles of hypoxia and the possible direct toxicity of anaesthetic agents have 


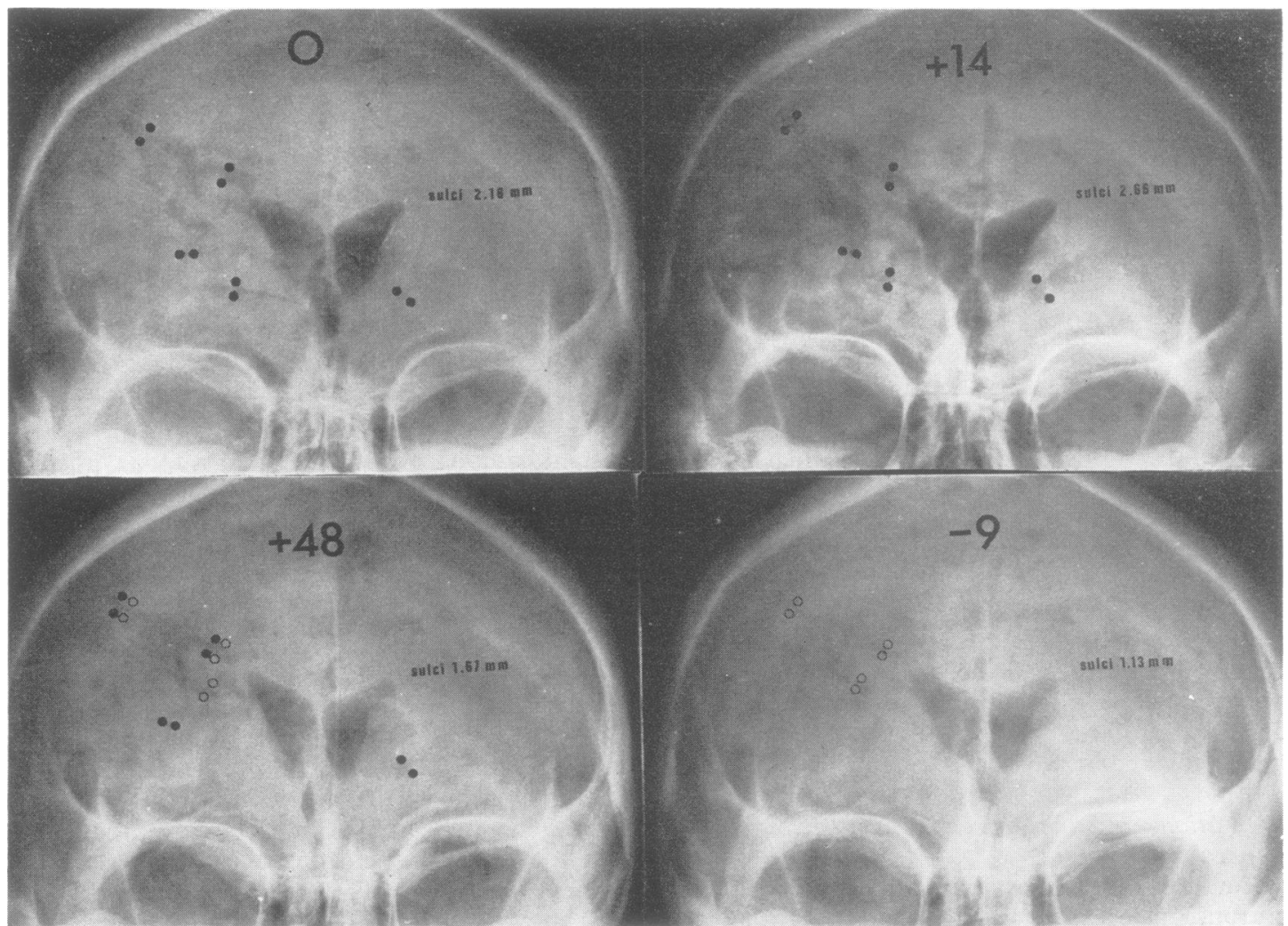

Fig. 6 Effects of exposure to nitrous oxide. Labels as in Fig. 3. Initial film: LeMay index 0.258. Mean sulcus diameter (solid dots): $2.18 \mathrm{~mm}$. +14: L.MI: $0.250(\Delta \%=-3.1)$. Mean sulcus diameter: $2.50 \mathrm{~mm}$ $(\Delta \%=14.7) .+48$ (after somersault): LMI: $0.261(\Delta \%=+12)$. Mean sulcus diameter (open circles only: sulci previously measured are not now visible): $1.67 \mathrm{~mm}$. -9: LMI: $0.249(\Delta \%=-4.6)$. Mean sulcus diameter: $1.3 \mathrm{~mm}(\Delta \%=-32.1)$.

Table 13 Effects of addition of nitrous oxide to inhaled gases on size of cerebral sulci

\begin{tabular}{|c|c|c|c|c|c|c|c|c|c|}
\hline \multirow[b]{3}{*}{ Patient } & \multirow{3}{*}{$\begin{array}{l}\text { Initial } \\
\text { mean sulcus } \\
\text { diameter }(\mathrm{mm})\end{array}$} & \multicolumn{8}{|c|}{ After addition of nitrous oxide } \\
\hline & & \multicolumn{2}{|l|}{$5 \min$} & \multicolumn{2}{|l|}{$6-10 \min$} & \multicolumn{2}{|l|}{$11-15 \min$} & \multicolumn{2}{|l|}{$15 \mathrm{~min}$} \\
\hline & & Sulci $(\mathrm{mm})$ & $\Delta \%$ & Sulci $(\mathrm{mm})$ & $\Delta \%$ & Sulci $(\mathrm{mm})$ & $\Delta \%$ & Sulci $(\mathrm{mm})$ & $\Delta \%$ \\
\hline EA & 2.07 & 2.17 & +4.8 & 2.32 & +12.1 & 2.37 & +14.5 & - & - \\
\hline IH & 4.13 & 4.50 & +8.4 & 4.55 & +10.2 & - & - & - & - \\
\hline MS & 1.12 & 1.37 & +22.3 & 1.48 & +32.1 & - & - & - & - \\
\hline AG & 2.18 & 2.40 & +10.1 & 2.66 & +22.0 & 2.50 & +14.7 & - & - \\
\hline HR & 1.10 & 1.22 & +10.1 & 1.60 & +45.5 & 1.57 & +42.7 & 1.80 & +63.6 \\
\hline DH & 1.66 & 1.70 & +2.4 & 1.69 & +1.8 & 1.50 & -9.6 & - & - \\
\hline FD & 0.95 & 0.98 & +3.2 & 1.27 & +33.7 & - & - & - & - \\
\hline CB & 1.00 & 0.98 & -2.0 & 1.03 & $\begin{array}{r}3.0 \\
+3\end{array}$ & 1.05 & +5.0 & - & - \\
\hline Mean & 1.77 & 1.92 & +7.5 & 2.10 & +20.1 & 1.80 & +13.5 & 1.80 & +63.6 \\
\hline SD & \pm 1.03 & \pm 0.86 & \pm 6.9 & \pm 1.03 & \pm 14.9 & \pm 1.24 & \pm 17.1 & 1 & - \\
\hline Significance $P=$ & & & 0.35 & & 0.30 & & 0.30 & & \\
\hline
\end{tabular}

never been assessed in this context. Campkin and Turner (1972) found that every one of 22 patients spontaneously breathing an oxygen/nitrous oxide/ halothane mixture during pneumoencephalo- graphy had a $\mathrm{PaCO}_{2}$ above 40 torr, and indeed in two patients the level was above 70 torr.

Although it is now our policy to carry out hyperventilation routinely during pneumoence- 
Table 14 Effects of withdrawal of nitrous oxide from inhaled gases on size of cerebral sulci

\begin{tabular}{|c|c|c|c|c|c|c|c|}
\hline \multirow[b]{3}{*}{ Patient } & \multirow{3}{*}{$\begin{array}{l}\text { Second initial } \\
\text { mean sulcus } \\
\text { diameter }(\mathrm{mm})\end{array}$} & \multicolumn{6}{|c|}{ After withdrawal of nitrous oxide } \\
\hline & & \multicolumn{2}{|l|}{$5 \min$} & \multicolumn{2}{|l|}{$6-10 \min$} & \multicolumn{2}{|l|}{$11-15 \mathrm{~min}$} \\
\hline & & Sulci $(\mathrm{mm})$ & $\Delta \%$ & Sulci $(\mathrm{mm})$ & $\Delta \%$ & Sulci $(\mathrm{mm})$ & $\Delta \%$ \\
\hline EA & 3.15 & 2.75 & -12.7 & 2.25 & -28.6 & - & - \\
\hline IH & 4.03 & 3.57 & -11.4 & 3.23 & -19.6 & - & - \\
\hline $\mathbf{A G}$ & 1.67 & 1.17 & -29.9 & 1.13 & -32.1 & - & - \\
\hline HR & 1.68 & 1.50 & -10.7 & 1.30 & -22.6 & 1.12 & -27.6 \\
\hline DH & 1.10 & 0.96 & -12.7 & 1.10 & 0.0 & - & - \\
\hline $\mathrm{CB}$ & 0.70 & 0.70 & - & - & - & - & - \\
\hline Mean & 2.05 & 1.78 & -12.9 & 1.80 & -20.6 & 1.12 & -27.6 \\
\hline SD & $\pm \mathbf{1 . 1 6}$ & \pm 1.35 & \pm 8.8 & \pm 0.82 & \pm 11.2 & - & - \\
\hline Significance $P=$ & & 0.35 & & 0.25 & & & \\
\hline
\end{tabular}

phalography, this was not the case when most of the examinations analysed in the present series were carried out. In the group of patients in whom the $\mathrm{PaCO}_{2}$ was monitored during the encephalogram, changes of up to 15 torr, sustained for as long as 10 minutes, did not produce significant changes in the size of the cerebral ventricles. The results, therefore, indicate that in serial studies of ventricular size it may not be necessary to take the $\mathrm{PaCO}_{2}$ into account, provided it is within the range covered here.

\section{Dilatation of the cerebral ventricles during general anaesthesia}

It has been clearly established that inhalation of nitrous oxide causes marked changes in the cerebrospinal fluid pressure relationships during pneumoencephalography. Attention was first drawn to the (potentially deleterious) effects of nitrous oxide anaesthesia by Saidman and Eger (1965), who showed that in both dogs and humans administration of nitrous oxide in routine anaesthetic concentrations caused the lumbar cerebrospinal fluid pressure to rise by more than $30 \mathrm{mmHg}$ when air was present in the subarachnoid space; this rise did not occur in the absence of subarachnoid air. Gordon and Greitz (1970) confirmed these findings: they found that the lumbar pressure rose when air was injected, even with the patients breathing air, but in nine of 11 cases it rose again much more sharply when nitrous oxide inhalation was begun; the two remaining patients had large ventricles. The rise in pressure occasioned by air injection was greater than normal if the patients were already breathing nitrous oxide; if, however, nitrous oxide was used as the contrast medium, subsequent inhalation of the gas produced no pressure change.

The elegant studies of Philippart et al. (1968) had shown that: (i) injection of air into the cerebrospinal fluid spaces in patients under nitrous oxide anaesthesia caused a larger and more con- sistent rise of pressure than a similar injection while the patients were breathing air; (ii) a gradual fall in pressure followed this initial increase; and (iii) the pressure could be maintained at the immediate post-injection level by withdrawal of cerebrospinal fluid, and that the amount of fluid required to achieve this was approximately equal in volume to the air injected when the latter was confined to the subarachnoid space, but only about $25 \%$ of the injected volume when the air was wholly intraventricular.

Campkin and Turner (1972) noted that the increase in cerebrospinal fluid pressure produced by air injection under nitrous oxide anaesthesia was greater when patients were hypercapnoeic.

The explanation offered for these observations hinges on the much greater solubility of nitrous oxide as compared with nitrogen (by a factor of 34, according to Mallamo et al. (1975)). The contrast medium (air) is effectively $80 \%$ nitrogen and $20 \%$ oxygen. Nitrous oxide is used as an anaesthetic agent in Great Britain in high concentration $-66 \%$ in the present study and most of those described here-although it is common to use it in 'analgesic' concentration (about 50\%) in the United States. The gas dissolves very rapidly in the blood and thence diffuses into the nitrogen and oxygen filled ventricles and subarachnoid space, where its initial partial pressure is zero. Indeed, so soluble and diffusible is it that its use has been shown to cause overinflation of the air-filled cuffs of latex endotracheal tubes (Stanley et al., 1974).

Philippart et al. (1968) suggested that the cerebrospinal fluid compartment is 'effectively indistensible', and explained the rise in pressure they observed as a direct result of this. Mallamo et al. (1975) described considerable increase in size of a subdural air bubble remaining after a craniotomy while the patient was maintained under anaesthesia with $50 \%$ nitrous oxide. Gas embolism via ventriculoatrial shunts was described in two cases having air in the cerebral ventricles by Paul and 
Munson (1976); in one of these a cardiac murmur due to the gas in the shunt could be reproduced at will by reintroducing nitrous oxide to the inhaled gases!

The subsequent fall in pressure while the patients continued to breathe nitrous oxide was attributed by Philippart et al. (1968) either to a slow diffusion of nitrogen from the injected air into the denitrogenated blood or to a reduction in the intracranial blood volume. In the light of our observations, the former is perhaps more likely; it should be noted that in the present series the 'control' group, who were breathing nitrous oxide throughout the procedure, showed a tendency to reduction in size of the ventricles.

The one example of the effects of withdrawal of nitrous oxide from the anaesthetic gases illustrated by the Belgian authors (their Fig. 3) shows a clear reduction in the apparent size of both the cerebral sulci and the lateral ventricles. In the same way as it diffuses rapidly from the blood into the gas bubbles in the cerebrospinal fluid, nitrous oxide can pass rapidly out again. Thus, Aird (1933) noted that after encephalography in the dog, whereas injected air was present for about seven days, nitrous oxide was no longer visible after two to three hours. Bergstrom et al. (1967) used a nitrous oxide/oxygen 3:1 mixture as both anaesthetic and contrast medium. About 90\% (including probably all the nitrous oxide) was absorbed in five hours, and the remainder over the next two days. These workers also noted that absorption was slower when all the gas was within the ventricles (the corollary of the observations of Philippart et al. (1968)). It might, therefore, seem desirable to use an anaesthetic gas as the contrast medium in encephalography, but apart from the technical problems, there are other possible hazards: Collan and Iivanainen (1969) reported a patient with markedly enlarged ventricles whose collapse during reversal of anaesthesia after an examination conducted in this way was attributed -on rather slender grounds-to overly rapid elimination of the gas from the ventricles.

Swelling of the brain after general anaesthesia There is no evidence that the brain swells after anaesthesia. Several workers have indicated that brain swelling occurs in experimental animals after exposure of the cerebral cortex to air (see Moseley and Sondheimer (1975) for discussion of this problem), but if this were the cause it would not explain the observed differences between local and general anaesthesia.
Ventricular shrinkage after general anaesthesia Such a decrease in the size of the ventricles-or a shrinkage relative to the increase in size seen after pneumoencephalography under local anaesthesia-could result from either the resorption of nitrous oxide from the ventricles when exposure to the gas ceases at the end of the examination (a suggestion supported by the observations of Philipart et al. (1968), Collan and Iivanainen (1969) and the present work), or from 'leaching out' of gases from the intracranial bubbles when the patients are given a high concentration of oxygen to breathe, as they frequently are during recovery from anaesthesia. That the latter phenomenon does occur was demonstrated by Schwab et al. (1937) and by Hauke et al. (1967); however, it seems to affect mainly the gas in the subarachnoid space, and not that in the ventricles (Holt, 1937). A further objection to the latter suggestion is that a substantial number of patients are not given oxygen after general anaesthesia, while many of the patients recovering from pneumoencephalography under local anaesthesia are also given oxygen.

The suggestion that the continued presence of gas in the ventricles is responsible for their enlargement is borne out by the observations of Moseley and Sondheimer (1975) that when patients are followed up for periods of longer than 24 hours, as the quantity of gas within them decreases, the ventricles show a progressive diminution in size.

Brain swelling during pneumoencephalography under local anaesthesia

As stated above, the available evidence suggests that brain swelling is more likely to occur under general anaesthesia. Hypoventilation can, of course, occur in sedated patients, but although the effects of this have not been assessed, the present studies do not indicate that it would be an important consideration. The serial studies of Moseley and Sondheimer (1975), in which the ventricles tended to return to the size of the first day, suggest that the latter was not artificially small.

Ventricular collapse under local anaesthesia Although there is considerable evidence that the ventricles dilate as air is injected (Koschewnikow, 1926; Robertson, 1946; Oberson et al., 1969; Lim et al., 1972; Probst, 1973), some workers claim to have shown that they subsequently become smaller (Jirout, 1956, Petrov, 1966, Øigaard, 1971; Probst, 1972). Subdural haematomas have been reported complicating pneumoencephalography (see Moseley and Pilling (1970) for bibliography), 
which may suggest that such a shrinkage occurs, although they could also be related to shrinkage of the cerebrum. If the tendency to ventricular collapse were not resisted-by diffusion of gas into the ventricles during the procedure, for examplethis could cause a reduction in ventricular size, but there is no reason why it should be temporary. Evidence from direct intracranial recording during pneumoencephalography, however, indicates that the pressure is raised even under local anaesthesia (Cronqvist et al., 1963) and not lowered, as would be expected if ventricular collapse were to occur.

Gawler et al. (1976), comparing the Evans's ratio (Evans, 1942) as seen at pneumography with that derived from computerised tomography (EMI scanning) of the same patients, found that ventricles of normal size appeared slightly larger on the air study, supporting the suggestion that the ventricles had dilated as a result of the introduction of air; they even noted focal dilatation of a portion of the lateral ventricles containing air in some cases studied by computerised tomography in the days after pneumography. When the ventricles were abnormally large, however, they appeared slightly smaller at pneumography than at computerised tomography, raising the possibility of some ventricular collapse. Three-quarters of the contrast studies had been carried out under general anaesthesia, but it it possible that these differences would have been more marked under local anaesthesia.

Active ventricular expansion after pneumoencephalography

This would appear, on the previously available evidence, to be the most likely cause of the increase in size of the ventricles. Such imperfect knowledge as we have of the mechanisms involved (Moseley and Sondheimer, 1975; Voigt and Stoeter, 1975) casts no light on the differences observed with different modes of anaesthesia. It does, however, seem clear that the volume of gas remaining within the ventricles is of fundamental importance, and as this is effectively decreased by the outward diffusion of gas that occurs at the termination of nitrous oxide anaesthesia, this would seem to be the most likely explanation for the differences.

\section{Shrinkage of the cerebrum}

Although Voigt and Greitz (1976) have shown that pneumoencephalography under local anaesthesia causes a marked decrease in cerebral blood volume, there is no reason to suggest that this persists after the examination and causes further shrinkage of the brain; indeed, their results indicate that it is a transitory phenomenon. Jährig and Zöllner
(1971) found that the cerebrospinal fluid was more alkaline after encephalography; although perfusion of the cerebral ventricles with alkaline fluid decreases central cerebral blood flow (Pannier $e t$ al., 1971/2), there is no apparent reason why this should be more marked after local anaesthesia.

\section{CHANGES IN THE CEREBRAL SULCI}

The changes in cerebral blood flow and volume produced by hyperventilation (McHenry et al., 1965) are associated with a diminution in intracranial tension (Bozza Marrubini et al., 1964). The present observations that a lowered $\mathrm{PaCO}_{2}$ (the $\mathrm{PaCO}_{2}$ being directly proportional to the endexpired $\mathrm{CO}_{2}$ concentration, in the absence of significant pulmonary disease, so that although the figures may not be precisely the same, the degree of change should correlate closely) was associated with an increase in the diameter of the sulci in seven out of nine cases-reversible in five-while the ventricles did not change in size, suggest that the effects of hyperventilation may be more marked on the cerebral cortex than on the white matter. This would correlate well with the known characteristics of cerebral blood flow and volume, both of which are greater in the grey matter than in the white (Wilkinson et al., 1969); it is also clear that the variations in blood flow and volume are greater in the grey matter (Iliff et al., 1974). Furthermore, not only is the superficial portion of the cerebrum composed of grey matter (while the frontal horns, at least, of the lateral ventricles are surrounded by white matter), but the actual surface of the brain is covered by blood vessels which react significantly to changes in $\mathrm{PaCO}_{2}$; if the amount of blood in the vessels lining a sulcus decreases, the volume of cerebrospinal fluid (or air) within the sulcus may increase. General anaesthesia with nitrous oxide, as used in the present studies, renders the cerebral vessels more reactive to changes in $\mathrm{PaCO}_{2}$ (Iliff et al., 1976), although the mechanisms involved are unknown.

In this context it is of some interest to note that while Evans (1942) found no change in the size of the lateral ventricles when children were given $50 \mathrm{ml}$ of $50 \%$ sucrose intravenously 24 hours after pneumoencephalography, Jirout (1956) was able to observe 'dilatation and blurring' of the subarachnoid space in $84 \%$ of 127 adults given $80 \mathrm{ml}$ of $40 \%$ glucose; he did not comment on the size of the ventricles.

Our data on the effects of nitrous oxide inhalation in causing enlargement of the gas bubbles in the sulci confirm earlier suggestions that this occurred. Some caution must be exercised, however, in extending this to infer that the size of the sulci 
actually changed. Accurate measurement is very difficult, partly because of the small size of the structures involved, but also because, since the walls of the sulci are often not parallel in the plane perpendicular to the overall surface of the brain, there is marked partial-volume effect. The complex form of the sulci also explains a further problem, which may be the most significant; a sulcus in which the cerebrospinal fluid in a wider, more superficial, or deeper portion than that initially filled is subsequently replaced by gas may appear to become larger, without any true change in the size of the solid structures in the vicinity. When the nitrous oxide was withdrawn from the anaesthetic mixture, many sulci apparently disappeared completely; it may be that, as the gas within them was absorbed, their sides became approximated, but it seems more likely that, at this stage, all the remaining gas within the sulci was nitrous oxide, which then redissolved in the cerebrospinal fluid.

Even when these caveats are taken into account, the sulci certainly do appear to increase in size as the nitrous oxide diffuses into them, and subsequently to decrease in size. The much more obvious changes occurring in the subarachnoid space than in the ventricles are probably related to the very different volume to surface area ratios of the large gas bubbles in the ventricles and the multiple small bubbles in the convexity cerebrospinal fluid spaces. The greater surface vascularity of the cortex as compared with the ependyma may also be significant. Whatever the mechanism, it has been recognised since the earliest days of encephalography that the air was absorbed much more rapidly from the surface of the brain than from the ventricles; this was quantitated in different disease groups by Aird and Zealear (1951). The present observation that the ventricles did not become larger as the extracerebral air was resorbed tends to confirm the earlier suggestion of Moseley and Sondheimer (1975) that this differential absorption was not the cause of postencephalographic ventricular enlargement, as suggested by Paul and Erickson (1946).

\section{Conclusion}

Expansion of the lateral ventricles after pneumoencephalography is less marked when the study is conducted under general anaesthesia with nitrous oxide than when local anaesthesia is used. This appears to be related to a slight expansion of the ventricles caused by the diffusion of nitrous oxide into the air within them during the procedure, and to rapid resorption of the gas when inhalation of nitrous oxide ceases.
Inhalation of nitrous oxide also causes the sulci to increase in size; the same phenomenon is observed with hyperventilation. Reduction of $\mathrm{PaCO}_{2}$ to around 25 torr is not associated with any change in size of the lateral ventricles.

Our thanks are due to the physicians and surgeons of the National Hospital for allowing us to carry out these studies on the patients under their care, to our anaesthetist colleagues for their patient collaboration, to the Department of Medical Illustration at the National Hospital for preparation of the illustrations, and to Miss Pauline Hampson for her considerable secretarial assistance.

\section{References}

Aird, R. B. (1933). Experimental encephalography with anaesthetic gases. Proceedings of the Society for Experimental Biology and Medicine, 31, 715-717.

Aird, R. B.. and Zealear, D. (1951). Pneumoencephalographic study of cerebrospinal fluid absorptive block mezhanisms. Archives of Neurology and Psychiatry (Chicago), 66, 199-212.

Bergstrom, K., Hogstrom, S., and Lodin. H. (1967). Experiences with nitrous oxide/oxygen as contrast medium in encephalography and ventriculography performed under general anaesthesia. Annales de Radiologie, 10, 189-191.

Bernini, F. P.. Calabro, A.. Mazzerella, B., and Smaltino, F. (1973). Controlled hyperventilation in fractional encephalography. Preliminary note. Neuroradiology. 5, 190-194.

Bohn, S. S. (1937). The reactions of patients to encephalography. An analysis of one thousand consecutive cases. Bulletin of the Neurological Institute of New York. 6, 540-568.

Bozza Marrubini, M., Rossanda, M.. and Tretola, L. (1964). The role of artificial hyperventilation in the control of brain tension during neurosurgical operations. British Journal of Anaesthesia, 36, 415-431.

Campkin. T. V., and Turner, J. M. (1972). Blood pressure and cerebrospinal fluid pressure studies during lumbar air encephalography. British Journal of Anaesthesia . 44, 849-853.

Collan, R.. and Iivanainen. M. (1969). Cardiac arrest caused by rapid elimination of nitrous oxide from cerebral ventricles after encephalography. Canadian Anaesthetists' Society Journal, 16, 519-524.

Cronqvist, S., Lundberg, N., and Pontín, U. (1963). Cerebral pneumography with continuous control of ventricular fluid pressure. Acta Radiologica, 1, 558-564.

Davidoff, L. M., and Dyke, C. G. (1937). The Normal Encephalogram. Lea and Febiger: Philadelphia.

Evans, W. A. (1942). An encephalographic ratio for estimating the size of the cerebral ventricles. Further experience with serial observations. American Journal of Diseases of Children, 64, 820-830.

Gawler, J.. du Boulay. G. H.. Bull. J. W. D.. and 
Marshall, J. (1976). Computerised tomography (the EMI scanner): a comparison with pneumoencephalography and ventriculography. Journal of Neurology, Neurosurgery, and Psychiatry, 39, 202211.

Ghersi, J. A., Nunziata, I., and Pedreira, E. (1947). Variaciones de las imágenes encefalográficas determinadas por la anestesia general. La Prensa Médica Argentina, 34, 1236-1241.

Gordon, E., and Greitz, T. (1970). The effect of nitrous oxide on the cerebrospinal fluid pressure during encephalography. British Journal of Anaesthesia, 42, 2-8.

Hauke, H., Schmitz, H. P., and Wenner, J. (1967). Pneumoencephalography: resorption of injected air after oxygen inhalation. Annales de Radiologie, 10, 185-188.

Holt, T. (1937). Discussion of Schwab et al. (1937).

Iliff, L., Zilkha, E., Bull, J. W. D., du Boulay, G. H., McAllister V. L., Marshall, J., Ross Russell, R. W., and Symon, L. (1974). Effect of changes in cerebral blood flow on proportion of high and low flow tissue in the brain. Journal of Neurology, Neurosurgery, and Psychiatry, 37, 631-635.

Iliff, L. D., Zilkha, E., du Boulay, G. H., Marshall, J., Moseley, I. F., Ross Russell, R. W., and Symon, L. (1976). Cerebrovascular carbon dioxide reactivity and conductance in patients awake and under general anesthesia. Neurology (Minneapolis), 26, 835-838.

Jährig, K., and Zöllner, H. (1971). Veränderungen des Saüren-Basen-Status im liquor cerebrospinalis unter der pneumencephalographie. Nervenarzt, 12, 152154.

Jirout, J. (1956). Changes in the size of the subarachnoid spaces after the insufflation of air. Acta Radiologica, 48, 81-86.

Koschewnikow, A. M. (1926). Subjektive und objektive Ergebnisse einer encephalographischen Untersuchung. Zeitschrift für des Gesamte Neurologie und Pyschiatrie, 104, 374-390.

LeMay, M. (1967). Ventricular size during and after pneumoencephalography. Radiology, 88, 57-63.

Lim, S. T., Potts, D. G., and Deck, M. D. F. (1972). Changes in ventricular size during fractional encephalography. Radiology, 104, 585-592.

Mallamo, J. T., Hubbard, R. B., Boone, S. C., Reisner, L. S., and Pister, J. D. (1975). Expansion of an air filled subdural space during nitrous oxide anesthesia. Radiology, 115, 369-372.

McDowall, D. G., Baker, J., and Jennett, W. B. (1966). Cerebrospinal fluid pressure measurements during anaesthesia. Anaesthesia, 21, 189-201.

McHenry, L. C., Slocum, H. C., Bivens, H. E., Mayes, H. A., and Hayes G. J. (1965). Hyperventilation in awake and anesthetised man. Effects on cerebral blood flow and cerebral metabolism. Archives of Neurology (Chicago), 12, 270-277.

Moseley, I. F., and Pilling, J. (1976). Intraocular haemorrhage as a complication of pneumoencephalo- graphy. Journal of Neurology, Neurosurgery, and Psychiatry, 39, 375-380.

Moseley, I. F., and Sondheimer, F. K. (1975). The twenty-four hour pneumoencephalogram: with particular reference to ventricular size. Clinical Radiology, 26, 389-405.

Oberson, R., Candjardis, G., and Raad, N. (1969). Height of fourth ventricle: normal variability during pneumography. Acta Radiologica, 9, 193-198.

Øigaard, A. (1971). Changes in ventricular size during pneumoencephalography. Neuroradiology, 3, 8-11.

Pannier, J. L., Weyre, J., and Leusen, I. (1971/2). Effects of changes in the acid-base composition in the cerebral ventricles on local and general blood flow. European Neurology, 6, 123-126.

Paul, L. W., and Erickson, T. C. (1946). Observations on the presence of subdural gas after pneumoencephalography. Radiology, 46, 138-148.

Paul, W. L., and Munson, E. S. (1976). Gas embolism during encephalography. Anesthesia and Analgesia. Current Researches, 55, 141-144.

Petrov, H. (1966). Neue Wege im der pneumencephalographie. Der Radiologe, 6, 503.

Philippart, C., Thibaut, A., and Bonnal, J. (1968). Effets de l'inhalation de protoxyde d'azote au cours des explorations neuroradiologiques realisées avec l'air. Neuro-chirurgie, 14, 97-104.

Probst, F. P. (1972). Rapid changes in the volume of the lateral ventricles at encephalography. Acta Radiologica, 12, 757-768.

Probst, F. P. (1973). Gas distension of the lateral ventricles at encephalography. Acta Radiologica, 14, $1-4$.

Robertson, E. G. (1946). Further Studies in Encephalography. MacMillan: Melbourne.

Saidman, L. J., and Eger, E. I. (1965). Change in cerebrospinal fluid pressure during pneumoencephalography under nitrous oxide anesthesia. Anesthesiology, 26, 26-72.

Schwab, R. S., Fine, J., and Mixter, W. J. (1937). Reduction of postencephalographic symptoms by inhalation of 95 per cent oxygen. Archives of Neurology and Psychiatry (Chicago), 37, 1271-1282.

Stanley, T. H., Kawamura, R., and Graves, C. (1974). Effects of nitrous oxide on volume and pressure of endotracheal tube cuffs. Anesthesiology, 41, 256-262.

Voigt, K., and Greitz, T. (1976). Cerebral blood volume alterations during fractional pneumoencephalography. American Journal of Roentgenology, 126, 582-592.

Voigt, K., and Stoeter, P. (1975). Polygraphic recordings of EEG, ECG and blood pressure before, during and after fractional pneumoencephalography. Neuroradiology, 9, 21-27.

Wilkinson, I. M. S., Bull, J. W. D., du Boulay, G. H., Marshall, J., Ross Russell, R. W., and Symon, L. (1969). Regional blood flow in the normal cerebral hemisphere. Journal of Neurology, Neurosurgery, and Psychiatry, 32, 367-378. 